\title{
Flavon Compound from The Ethyl Acetate Extract of The Stem of Supit (Tetracera indica Merr.)
}

\author{
Muharni*, Elfita, Riska Adillah, Heni Yohandini, Julinar \\ Department of Chemistry, Faculty of Mathematics and Natural Sciences, Sriwijaya University, \\ Palembang, Indonesia \\ *email: muharnimyd@yahoo.co.id
}

Received November 20, 2017; Accepted March 21, 2018; Available online May 31, 2018

\begin{abstract}
Tetracera indica Merr. in Musi Banyuasin, is one of the traditional medicine used by the community for the treatment of kidney stone disease and gout, but this claim is not recorded in the treatment of kidney stones and gout in Indonesia. In this study, isolation of antioxidant compound from ethyl acetate extracts of supit (Tetracera indica) was done. The isolation was carried out through step gradient polarity extraction, and separated and purified by chromatography technique. The determination of the structure of the isolated compound was performed by spectroscopy method including UV, IR, and NMR 1D and 2D, and antoxidant activity was determined by DPPH method. An active antioxidant compound was isolated from ethyl acetate extract in form of yellow solid $(15 \mathrm{mg})$. Based on spectroscopic analysis the isolated compound was 5,8dihydroxy-7-methoxyflavone. The compound showed strong antioxidant activity $\left(\mathrm{IC}_{50} 8.25 \mu \mathrm{g} / \mathrm{mL}\right)$ higher than standard ascorbic acid ( $\left.\mathrm{IC}_{50} 11.3 \mu \mathrm{g} / \mathrm{mL}\right)$. This data concluded that efficacy of supit (Tetracera indica) for the treatment related to antioxidant activity (uric acid) is proven by the identification of one antioxidant compound of this plant.
\end{abstract}

Key word: Flavon, ethyl acetate extract, Tetracera indica, antioxidant

\section{INTRODUCTION}

Indonesia is a country with the second largest diversity of plants in the world, but there are still many medicinal plants that have not been fully utilized (Hanafi, Nina, Zorni, and Nurbaiti, 2005). The use of medicinal plants has been practiced by the Indonesian people for generations. Indonesian herbal medicines are used based on empirical practice: diseases preventive $(48.9 \%)$ (Hanafi et al, 2005). Although modern medicine has grown tremendously in Indonesia, but traditional medicine is still very popular in rural as well as in urban areas (Elfahmi, Herman, Woerdenbag, and Oliver, 2014). Moreover to having a high diversity of plants, Indonesia is also rich with tribal and cultural diversity (Ernie, 2013). In some tribes, endemic plants was found to be used as traditional treatment. Some times in some tribes are found endemic plants used for traditional treatment.

In previous research has been done exploration and inventory of medicinal plants and their utilization in society based on local resources. One of them is the ethnic Musi in Musi Banyuasin district of South Sumatra. In research of medicinal plants and herbal medicine has been identified 95 species of medicinal plants (Yustian, Muharni, Sukarmi,
Zulaicha, and Arbi, 2012). From the 20 selected plant, 9 species of them are traditionally used for the treatment of diseases atherosclerosis, diabetes , prostate, gout, and kidney stones. These types of diseases are related to free radical activity (Paravicini and Touyz, 2008). In vitro antioxidant activity test of 9 selected plant extracts is one of them is supit stems, showed high antioxidant activity with value of $\%$ inhibition $69.6 \%$ at test concentration $1000 \mathrm{ppm}$. Based on literature study of extracts that showed antioxidant activity $>50 \%$ categorized as active source of antioxidant compound (Chaudhary, Bhandari, and Pandurangan, 2011; Muharni, Fitrya, and Nurmaliana, 2016).

Plants produce a wide diversity of secondary metabolites exhibit and a wide array of biological and pharmacological properties (Michael, 2015). Secondary metabolites from plants are the basis for many drugs currently used to treat various diseases, including diseases related to radical activity (Rogerio, Sá-Nunes, and Faccioli, 2010). Phytochemical tests of ethanol ektract of supit (Tetracera indica) have been performed and exhibited positive phenolic compounds. Phenolic compounds are generally active as antioxidant (Kenari, Mohsenzades, and Amiri, 2014; Brewer, 2011; Kumar, Mishra, and Pandey, 
2013). The limited ingredients available medicines has prompted researchers to explore the potential of nature to find new bioactive compounds.

Chemical compounds from leaf of supit (Tetracera indica) has been reported 4 terpenoid compounds: $\beta$-sitosterol, lupeol, Betuline, betulinic acid and 6 compounds flavonoid 5, 7-dihydroxy-8-methoxylavone or another name (Wogonin), 5, 7,8tryhydroxyflavone, isocutellarein methyl ether, kaemferol, quersetin, tetrokrisin (Dogarai, 2011). The methanol extract leaf of the supit showed activity as antidiabetic (Ahmed, Dogarai, Amiroudine, Taher, Latip, Umar, and Muhammad, 2012). Other research Fitrya, Muharni, and Maretha (2012) reported one phenolic compound from ethyl acetate extract of fruit.

In another study of Tetracera indica leaf extract containing flavonoid wagonin compound was active as an antibacterial (Lima, Lemos, and Conserva, 2014). Abdullah, Ismail, Jamaludin, and Mashim (2013) reported that the stems of supit show activity as antihiperuricemia, antidiabetic and anti-inflammatory and two compound has been reported of stem supit that is betulinic acid and 5,7-dihydroxyl-8-methoxyflavone. In this paper will be reported antioxidant compound active by DPPH method from ethyl acetate extract stem of supit.

\section{EXPERIMENTAL SECTION}

\section{Material}

The stem of Tetracera indica $(2 \mathrm{~kg})$ were collected from Ngulak I village Musi Banyuasin South Sumatera in June 2017. The botanical identification of the samples was confirmed by Dr. Laila Hanum. A voucher specimen (number VIC 2701) was deposited at the Herbarium Department Biology Sriwijaya University. Material for isolation: silica gel 60 (70 -230 mesh.), thin layer chromatography (TLC) using Merck (Art.5554), silica gel G 60 $(70$ - 230), methanol p.a, n-hexane p.a, ethyl acetate p.a, chloroform p.a acetone p.a, distilled water. Reagent for antioxidant activity: DMSO (dimethyl sulfoxide), DPPH (1,1-diphenyl-2-picrylhydrazyl), and ascorbic acid.

\section{Instrumentation}

The apparatus in the research were rotary evaporator R-114 Buchi, column chromatography $(\mathrm{CC}), \quad$ ultra-violet lamps CAMAG $254 \mathrm{~nm}$, radiation $(\lambda=254$ and 365 $\mathrm{nm})$. Fisher Jhon melting point apparatus, spectrophotometer ultraviolet Beck DU-7500. FTIR-Perkin Elmer, NMR JEOL JNM ECA500 spectrometer. UV-visible spectrophoto meter using a single beam provided by Shimadzu-UV mini 1240 instrument, and commonly used glassware in the organic laboratory.

\section{Preparation of Extracts}

The stem of Tetracera indica were dried at $30{ }^{\circ} \mathrm{C}$ for 20 days with continuous moisture monitoring. After the material was completely dry, it was pulverized in a knife grinder, obtained $550 \mathrm{~g}$ of sample. The dried stem bark were subjected to exhaustive extraction in maceration apparatus using an increasing polarity solvent system, with nhexane, ethyl acetate and ethanol as solvents each for $24 \mathrm{~h}$. The extracts were then concentrated at reduced pressure used Rotary evaporator. Each of the extracts was tested antioxidant activity.

\section{Evaluation of Antioxidant Activity of Each Extract}

The antioxidant activity test was performed using DPPH radical-scavenging activity (Selvi, Joseph, and Jayaprakasha, 2003; Tuanjai, Supalax, Thawatchai, and Wittaya, 2011). The concentration series for extract :1000, 500, 250, 125, 62.5 and 31.25 $1000 \mu \mathrm{g} / \mathrm{mL}$ (in DMSO) was prepared. 0.2 $\mathrm{mL}$ aliquot of sample solution was mixed with $3.8 \mathrm{~mL}$ of DPPH $(0.5 \mathrm{mM}$ in methanol) where $1.98 \mathrm{mg}$ DPPH was placed on a $100 \mathrm{~mL}$ volumetric flask then add methanol until the volume $100 \mathrm{~mL}$. This mixture was shaken at room temperature for $30 \mathrm{~min}$.

The absorbance of the mixture was then measured by UV-Vis spectrophotometer at $\lambda_{\max }$ $517 \mathrm{~nm}$ (Selvi et al., 2003). For positive control (standard) used ascorbic acid and negative control (blank) used methanol. Isolated compound solution was analyzed in triplicate, The radical-scavenging activity was evaluated as the percentage of inhibition according to the following equation: \%inhibition $=[($ absorbance of control absorbance of sample)/ absorbance of control)]x 100 (Delwar, Shahid, Masudur, Shohel, Shahid, and Mohammad, 2014) and the average values were plotted to obtain the $\mathrm{IC}_{50}$ against $\mathrm{DPPH}$ by linear regression. 
Table 1. Antioxidant activity of each extract

\begin{tabular}{ccccccc}
\hline \multirow{2}{*}{ Concentration } & \multicolumn{2}{c}{ Extract n-hexane } & \multicolumn{2}{c}{ Extract Ethyl acetate } & \multicolumn{2}{c}{ Extract Ethanol } \\
& Absorbance & \% inhibition & Absorbance & \% inhibition & Absorbance & $\%$ inhibition \\
\hline 1000 & 0.577 & 29.63 & 0.081 & 90.12 & 0.047 & 94.27 \\
500 & 0.589 & 28.17 & 0.140 & 82.93 & 0.052 & 93.65 \\
250 & 0.590 & 28.05 & 0.353 & 56.95 & 0.063 & 92.32 \\
125 & 0.592 & 27.80 & 0.469 & 42.80 & 0.074 & 90.97 \\
62.5 & 0.620 & 24.39 & 0.534 & 34.88 & 0.075 & 90.85 \\
31.5 & 0.679 & 17.20 & 0.547 & 33.29 & 0.078 & 90.49 \\
\hline
\end{tabular}

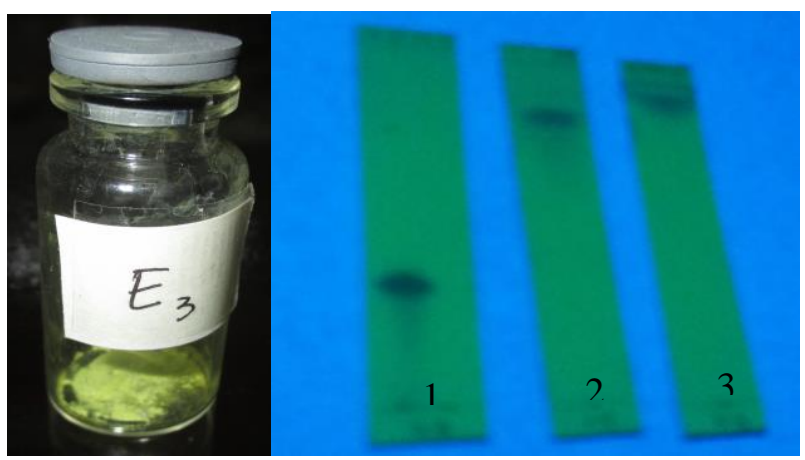

Figure 1. TLC isolated compound by eluents : n-hexane : ethyl acetate $9: 1(1) ; 5: 5(2)$ and EtOAC : $\mathrm{MeOH} 9.5: 1.5$ (3).

\section{Isolation and Purification Antioxidant Compound from Ethyl Acetate Extract}

Ethyl acetate extract $(3.5 \mathrm{~g})$ was separated by silica column chromatography using silica $\mathrm{G} 60 \mathrm{~F}_{254}$ (230-400 mesh), eluted with gradient polarity mixtures of hexaneethyl acetate ( 9: $1-5: 5$ ) were collected. Base on TLC analysis merged into six fraction F1 ( vials $1-5 ; 25 \mathrm{mg}$ ), F2 ( vials 7- 23; 1300 $\mathrm{mg}$ ), F3 (vials $26-67 ; 250 \mathrm{mg}$ ), F4 (vials 68 - 80; $500 \mathrm{mg}$ ), F 5( vials $81-84 ; 100 \mathrm{mg}$ ), and F 6 ( vials $85-95 ; 700 \mathrm{mg}$ ). From the selected fractions, the $4^{\text {th }}$ fraction $(500 \mathrm{mg})$ was further purified by re-chromatography using silica gel 60 (70 - 230 mesh), eluted with gradient polarity mixtures of n-hexane-ethyl acetate $(9: 1-7: 3)$ each $150 \mathrm{~mL}$.

Base on TLC analysis to obtained four sub fractions $\mathrm{F}_{4.1}$ (vials $1-3 ; 23 \mathrm{mg}$ ), $\mathrm{F}_{4.2}$ (vials $4-8 ; 44 \mathrm{mg}$ ), $\mathrm{F}_{4.3}$ ( vials $9-14 ; 84 \mathrm{mg}$ ) dan $\mathrm{F}_{4.4}$ (vials $15-44 ; 194 \mathrm{mg}$ ). Sub fraction $\mathrm{F}_{4.3}$ was re-chromatography using the same method (silica gel, eluted with gradient polarity mixtures n-hexane - EtOAc $(9: 1)$ to yield three fraction $F_{4.3 .1}(15 \mathrm{mg}), F_{4.3 .2}(50$ $\mathrm{mg}$ ). Fractions $\mathrm{F}_{4.3 .1}$ obtained yellow solid (15 $\mathrm{mg}$ ) and after analyzed with TLC showed one spot so it was pure compound.

\section{Elucidation Structure}

The structure of the isolated compound was elucidated using UV, IR, NMR $1 \mathrm{D}\left({ }^{1} \mathrm{H}\right.$ and ${ }^{13} \mathrm{C}$ NMR, DEPT), and NMR 2D (HMQC, and $\mathrm{HMBC}$ ) spectroscopy and by comparison with data from the literature.

\section{Evaluation Antioxidant Activity of Isolated Compound}

The pure isolated compound was determined antioxidant activity by the same procedure as the antioxidant activity assay of the extract but using the concentration 100, $50,25,12.5$ and $6.75 \mu \mathrm{g} / \mathrm{mL}$.

\section{RESULTS AND DISCUSSION}

The stem of supit ( $2 \mathrm{~kg}$ ) after dried obtained $550 \mathrm{~g}$ of powder. The powder Tetracera indica of $550 \mathrm{~g}$ was extracted with n-hexane solvent, ethyl acetate and ethanol respectively and after concentrated was obtained n-hexane extract $250 \mathrm{mg}$, ethyl acetate $3,50 \mathrm{~g}$ and ethanol extract $3.7 \mathrm{~g}$. Each extract, has been done antioxidant activity test with varying concentration (Table 1). Mariod, Matthaus and Hussein, (2008) state that the value of antioxidant activity is determined based on the value of percentage inhibition, the higher the value of the inhibition, the higher the antioxidant activity.

Table 1 showed that at the same concentration $1000 \mu \mathrm{g} / \mathrm{mL}$, the ethanol extract showed the highest activity with inhibition $94.27 \%$ followed by ethyl acetate extract with inhibition $90.12 \%$. Meanwhile, nhexane extract only gives an inhibition of 
29.63\%. Extracts are categorized potent containing antioxidant compounds when its have percent inhibition $>50 \%$ at a concentration of $1000 \mu \mathrm{g} / \mathrm{mL}$ (Chaudhary et al., 2012). Based on this data it is stated that the extract of ethyl acetate and ethanol extract from stems of supit (Tetracera indica) potentially contain antioxidant compounds. The Compounds that exhibit antioxidant activity generally provide fluorescent under UV light at a wavelength of $\lambda 365 \mathrm{~nm}$. Ethyl acetate extract after separation and purification a compound was isolated from the ethyl acetate extract of steam $T$. indica. The isolated compound was as a yellow solid (15 $\mathrm{mg}$ ). The purity test of the isolated compound was carried out by TLC analysis using various eluents : n-hexane : ethyl acetate $(9: 1 ; 5: 5)$ and EtOAC : $\mathrm{MeOH}(9.5: 1.5)$ showed a single spot on the UV lamp at $\lambda 365 \mathrm{~nm}$ (Figure 1).

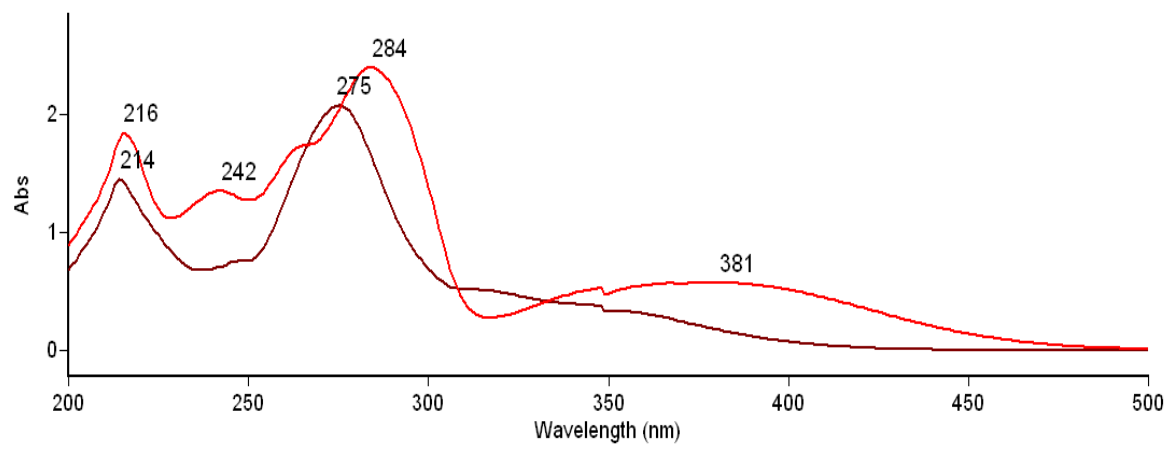

Figure 2. UV Spectrum of isolated compound.

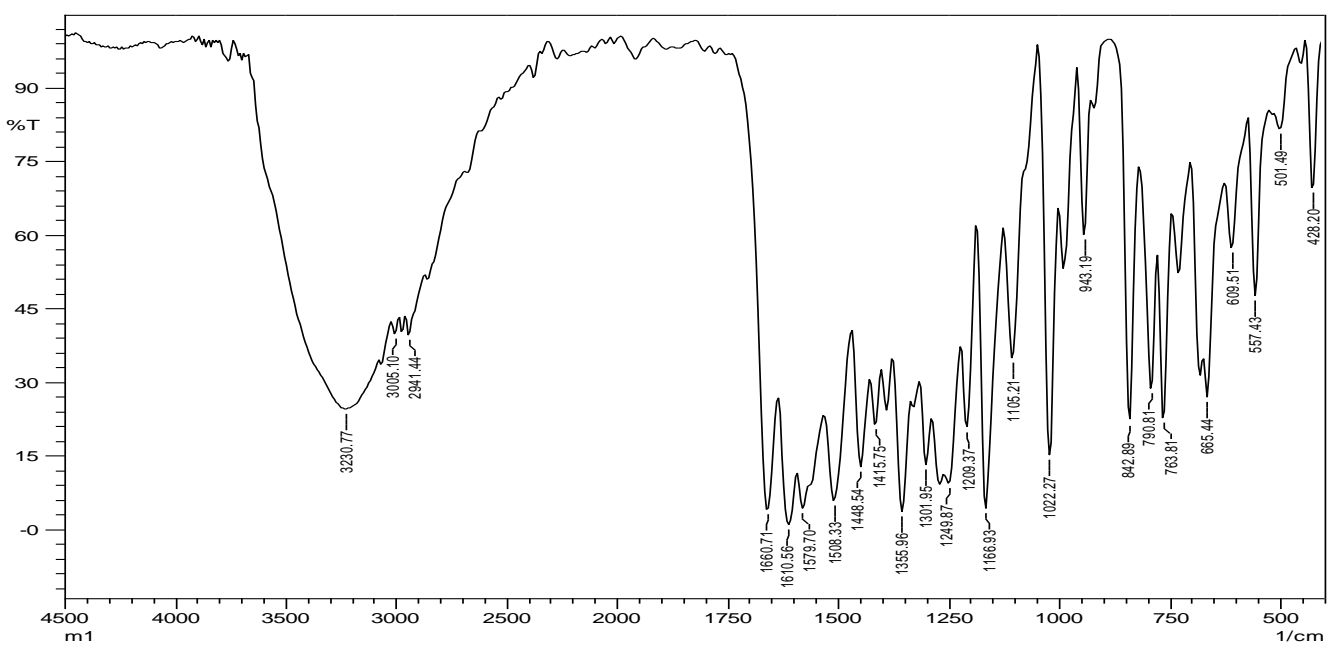

Figure 3. IR spectrum of isolated compound.

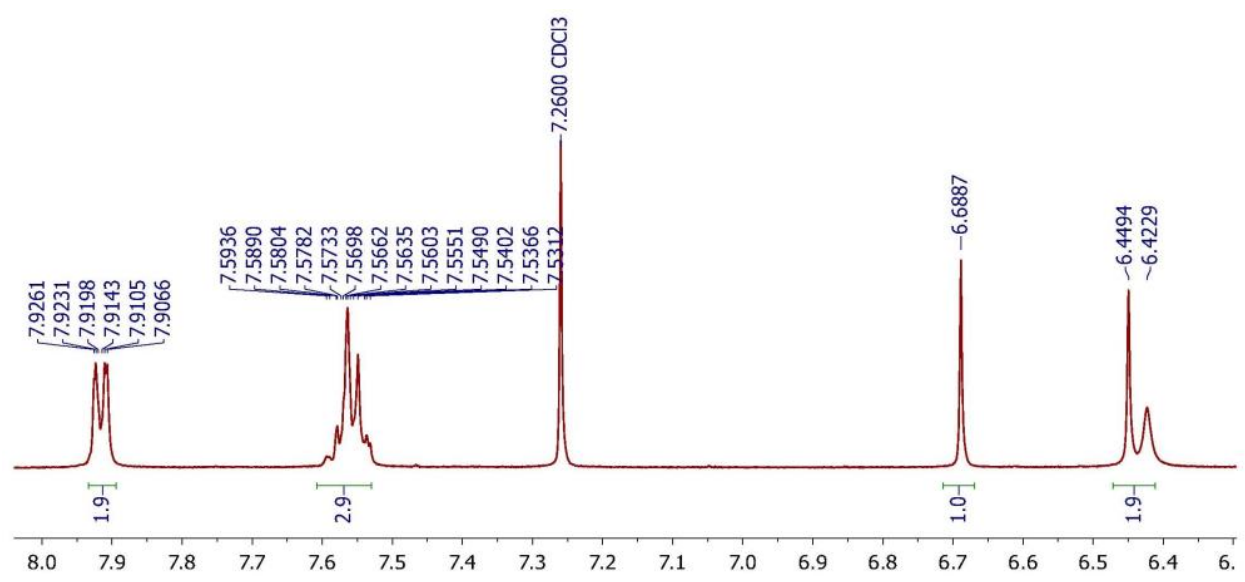

Figure 4. Spectra ${ }^{1} \mathrm{H}$ NMR of isolated compound 
The purity test of isolated compound were also conducted with measurement of the melting point. The measurement result obtained isolation compound have melting point is 203$205{ }^{\circ} \mathrm{C}$, the narrow melting point range $(\leq 2$ ${ }^{\circ} \mathrm{C}$ ) showed the isolated compound was pure.

\section{Determination Structure of The Isolated Compound}

Structural determination was done through spectroscopic analysis using several methods of spectroscopy UV, IR, NMR 1D ( ${ }^{1} \mathrm{H}$ NMR, ${ }^{13} \mathrm{C}$ NMR, dan DEPT) and NMR 2D (HMBC, HMQC). The UV spectrum (Figure 2) shows the maximum absorption at $\lambda_{\max } 275$ $\mathrm{nm}$ which is the absorption for the conjugated $\mathrm{C}=\mathrm{C}$ bond. The addition of $\mathrm{MeOH}$ as a shear reagent causes a maximum wavelength shift to $\lambda_{\max } 284 \mathrm{~nm}$, indicating the presence of $\mathrm{OH}$ phenolic. The measurement of the infrared spectra of the isolated compound with $\mathrm{KBr}$ pellet shows the absorption on $v_{\max } \mathrm{cm}^{-1}$ 3230.77 with a wide peak shape indicating that the $\mathrm{OH}$ group having hydrogen bond, 1660.71 (conjugated $\mathrm{C}=\mathrm{O}$ ), 1415.76; 1508.33; dan 1448.54 ( $\mathrm{C}=\mathrm{C}$ conjugation), and 1166.93 (C$\mathrm{O}$ ether). Based on the absorption of IR, it is suspected that the isolated compound is a flavonoid group in which literature study the
IR for flavonoids such as morelloflavon as reported by Muharni, Elfita, and Amanda (2011) provides absorption on $0_{\text {maks }} 3263$ (OH group). 1643 (conjugated $\mathrm{C}=\mathrm{O}$ ), ; 1552; $1514 ; 1439(\mathrm{C}=\mathrm{C}$ aromatic $)$ and $1180 \mathrm{~cm}^{-1}$ (C-O ether).

The ${ }^{1} \mathrm{H}$ NMR spectrum of the isolated compound (Figure 4) show the proton signal of methoxy at $\delta_{\mathrm{H}} 4.04(3 \mathrm{H}, s)$ and the signal of the aromatic proton at the $\delta \mathrm{H} 6.0-8.0 \mathrm{ppm}$. Signals at $\delta_{\mathrm{H}} 6.43(1 \mathrm{H}$, brs $)$ with widened peaks are signals for phenolic $\mathrm{OH}$. Signals at $\delta_{\mathrm{H}} 6.45 \mathrm{ppm}(1 \mathrm{H}, s)$ and $6.69(1 \mathrm{H}, s)$ are 2 non-split aromatic protons, 7,54 - 7,56 $(3 \mathrm{H}, m)$ are 3 proton aromatics that split with protons at $\delta_{\mathrm{H}} 7.91(2 \mathrm{H}, d d J=3.85)$ and signal at $\delta \mathrm{H}$ $12.49(1 \mathrm{H}, s)$ are signal for proton $\mathrm{OH}$ chelate. The ${ }^{13} \mathrm{C}$ NMR spectrum of the isolated compound showed 14 signals. Signal $\delta_{\mathrm{C}} 62.2$ $\mathrm{ppm}$ is characteristic signal for methoxy carbon. Signals at $\delta_{C} 99.00-165 \mathrm{ppm}$ are signals for $\mathrm{C} \mathrm{SP}^{2}$ from aromatic carbon. The signal at $\delta_{\mathrm{C}} 182.4 \mathrm{ppm}$ is a signal for $\mathrm{C}$ carbonyl in the form of a ketone. In HMQC spectrum (Figure 6) showed proton methoxy at $\delta_{\mathrm{H}} 4.04 \mathrm{ppm}$ bound to carbon $\delta_{\mathrm{C}} 62.2 \mathrm{ppm}$ and on spectrum of HMBC showed correlation with carbon at $\delta_{\mathrm{C}} 127.0 \mathrm{ppm}$.

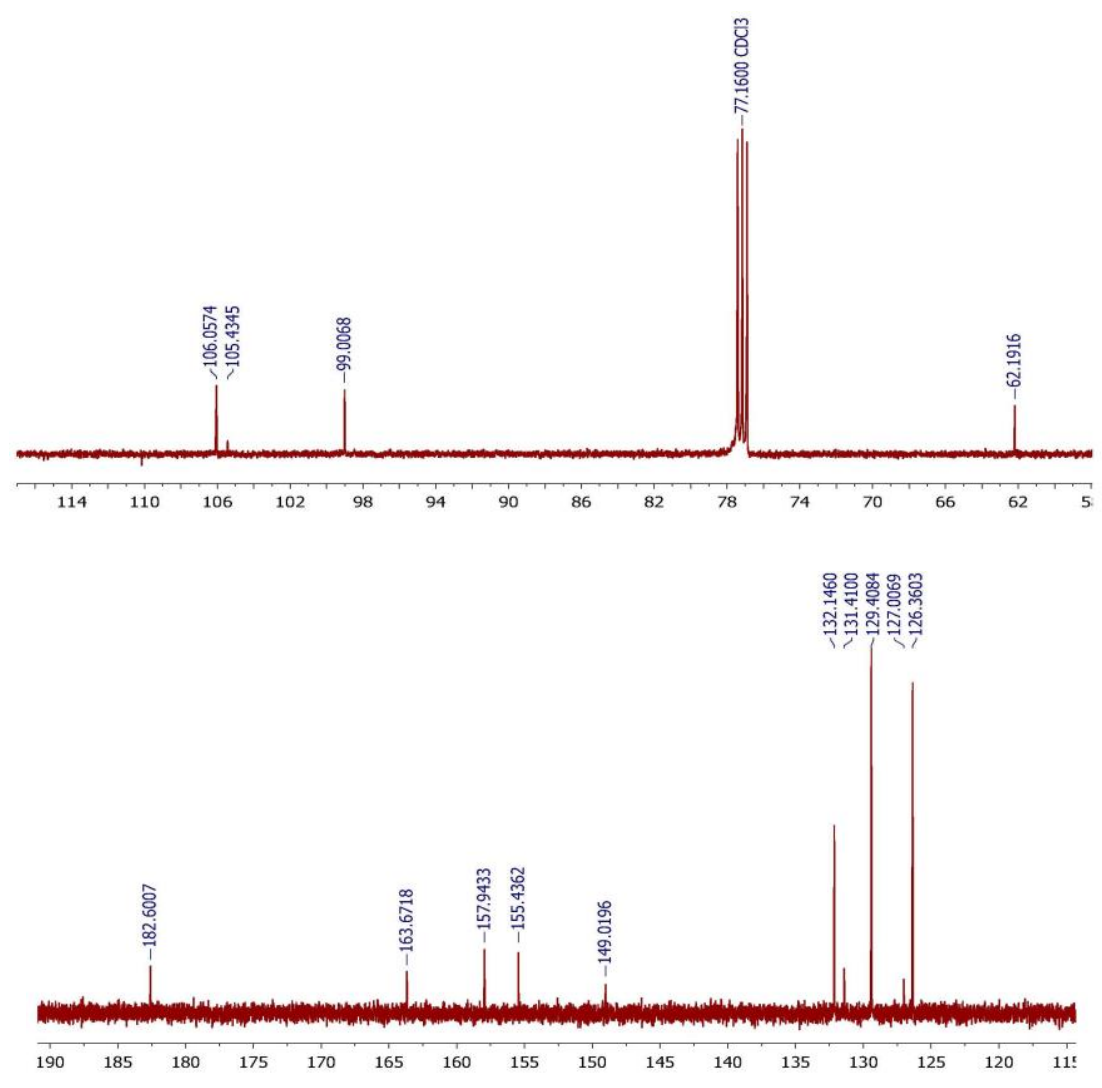

Figure 5. Spectrum ${ }^{13} \mathrm{C}$ NMR isolated compound. 


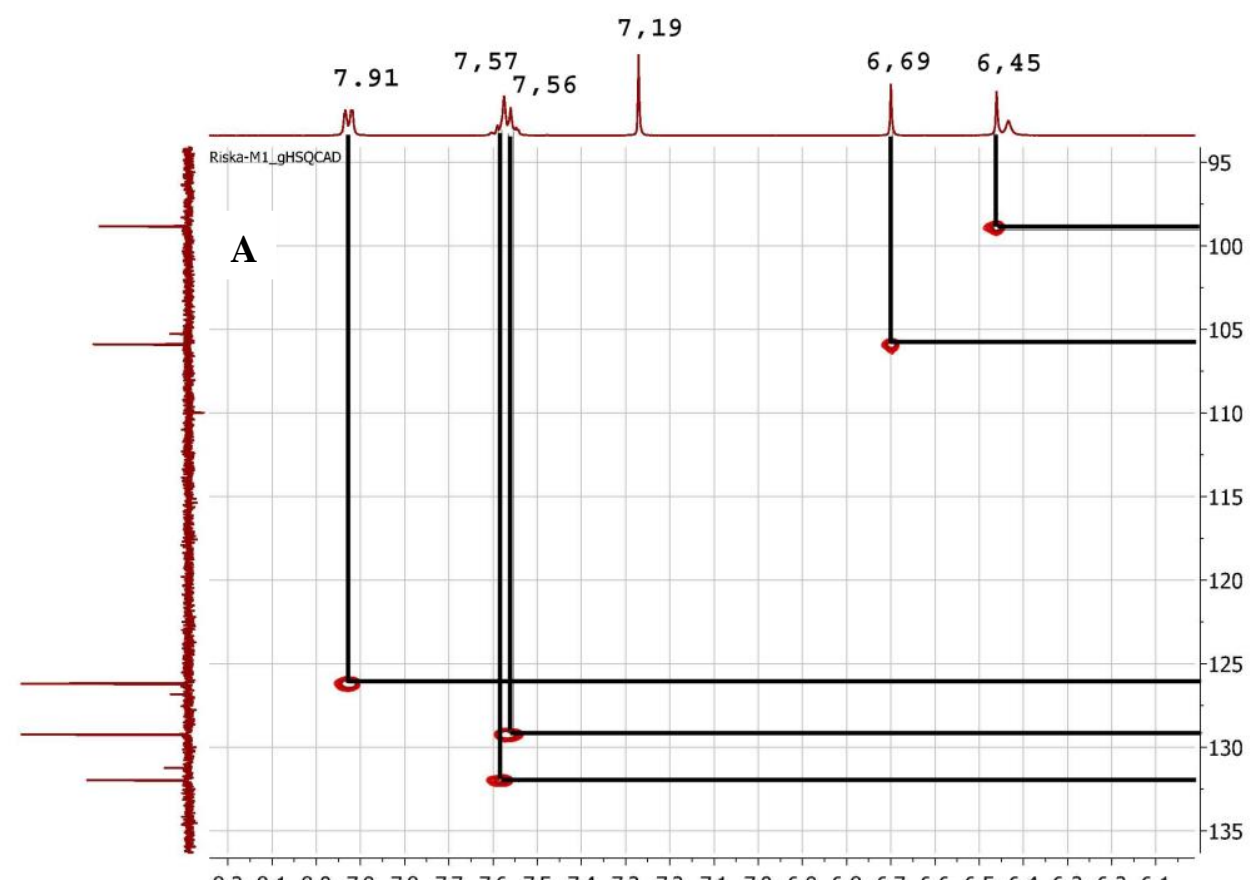

$\begin{array}{llllllllllllllllllllll}8.2 & 8.1 & 8.0 & 7.9 & 7.8 & 7.7 & 7.6 & 7.5 & 7.4 & 7.3 & 7.2 & 7.1 & 7.0 & 6.9 & 6.8 & 6.7 & 6.6 & 6.5 & 6.4 & 6.3 & 6.2 & 6.1\end{array}$

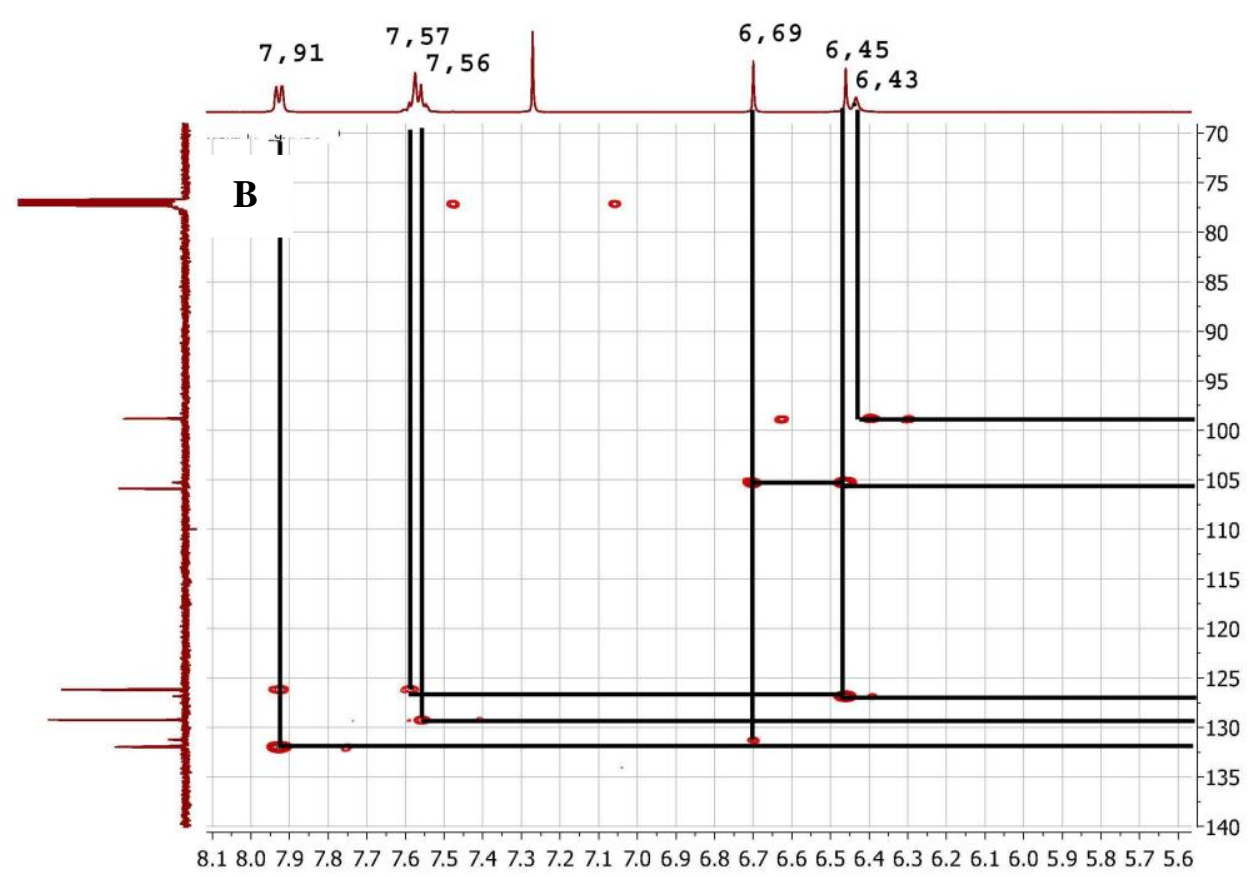

Figure 6. Spectrum HMQC at $\delta_{\mathrm{H}} 3.2-8.4 \delta \mathrm{C} 60-135 \mathrm{ppm}(\mathrm{A})$ and $\mathrm{HMBC}$ at $\delta_{\mathrm{H}} 5.6-8.1 \delta_{\mathrm{C}} 700$ $-140 \mathrm{ppm}(\mathbf{B})$

The HMQC spectrum also showed proton at $\delta_{\mathrm{H}} 6.45 \mathrm{ppm}(1 \mathrm{H}, s)$ and $\delta_{\mathrm{H}} 6.69(1 \mathrm{H}$, $s)$ respectively bound to carbon at $\delta_{\mathrm{C}} 99.0 \mathrm{ppm}$ and $\delta_{\mathrm{C}} 105.4 \mathrm{ppm}$. In the HMBC spectrum (Figure 6) showed protons at $\delta_{\mathrm{H}} 6.45 \mathrm{ppm}$ $(1 \mathrm{H}, \mathrm{s})$ correlated with carbon at $\delta_{\mathrm{C}}$ 106.1(C10), 127.0 (H8) 155.4 (C7), 157.9 ppm (C9). Meanwhile the proton at $\delta_{\mathrm{H}} 6.69(1 \mathrm{H}, \mathrm{s})$ correlated with carbon at $\delta_{\mathrm{C}} 106.1$ (C10), 131.4 (1') 163.5 (C2), 182.4 ppm (C4). This indicates the carbon at $\delta_{\mathrm{C}} 106.1 \mathrm{ppm}$ was located between the carbon at $\delta_{\mathrm{C}} 99.0$ and $105.4 \mathrm{ppm}$.

The HMQC spectrum also showed proton at $\delta_{\mathrm{H}} 7.56(2 \mathrm{H}) \mathrm{ppm}, 7.57(1 \mathrm{H}, s)$ and $7.91 \mathrm{ppm}(2 \mathrm{H})$ respectively bound to carbon respectively $\delta_{\mathrm{C}} 126.4132 .2$ and $129.4 \mathrm{ppm}$. Based on the integration of the aromatic proton $\delta \mathrm{H} \mathrm{7,56}$ and 7,91 respectively 2 protons then it is assumed the carbon signals at $\delta_{\mathrm{C}} 126.4$ and 129.4 ppm were signals each representing 2 carbon. 

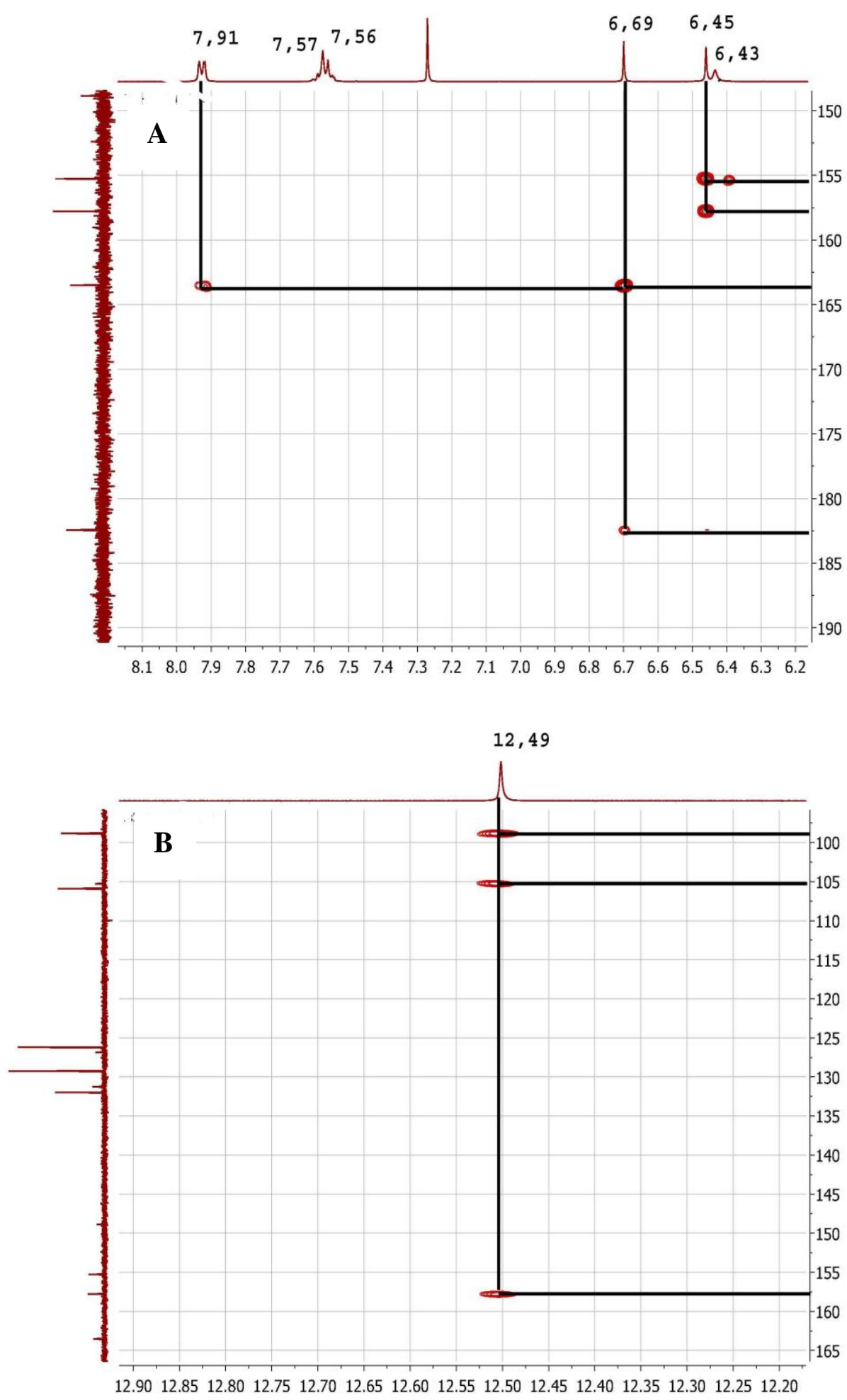

Figure 7. Spectrum $\mathrm{HMBC}$ at $\delta_{\mathrm{H}} 6.2-8.1 \mathrm{ppm}$ and $\delta_{\mathrm{C}} 12.2-12.9 \mathrm{ppm}$ and $\delta_{\mathrm{H}} 100-165 \mathrm{ppm}$.

Based on this HMQC data the number of carbon signals is 16 signals and the compound has an aromatic group in the form of mono substitution. In the HMBC spectrum the proton signals at $\delta_{\mathrm{H}} 7.56 \mathrm{ppm}$ correlate with the carbon at $131.4\left(1^{\prime}\right), 129.4 \mathrm{ppm}\left(\mathrm{C}^{\prime}, 5^{\prime}\right)$, meanwhile the signal at $\delta_{\mathrm{H}} 7.91 \mathrm{ppm}$ Showed correlated with carbon at $\delta_{\mathrm{C}} 126.4\left(2^{\prime}, 6^{\prime}\right)$, $132.1 \mathrm{ppm}$ (C4'). This suggests that the protons at $\delta_{\mathrm{H}} 7.56$ and $\delta_{\mathrm{H}} 7.91 \mathrm{ppm}$ were in adjacent $\mathrm{C}$ positions.

Furthermore, it was also seen in the HMQC spectrum where proton at $\delta_{\mathrm{H}} 12.49$ ppm bound to carbon at $\delta_{\mathrm{C}} 163.76 \mathrm{ppm}$ and on 
the HMBC spectrum this proton visible correlated with carbon at $\delta_{\mathrm{C}} 99.0 ; 105.4$ and $157.9 \mathrm{ppm} \delta_{\mathrm{C}} 99.0 ; 106.1 \mathrm{ppm}$. This indicates that this hydroxyl proton is a chelated proton adjacent to a proton $\delta_{\mathrm{H}} 6.45 \mathrm{ppm}$. The correlation between proton and carbon is shown in Figure 8. Based on UV IR, NMR 1d and $2 \mathrm{D}$ spectroscopy data, it was concluded that isolation compound was flavonoid 5,8dihydroxy-7-methoxyflavone with molecular formula $\mathrm{C}_{16} \mathrm{H}_{12} \mathrm{O}_{5}$ with the structure shown in Figure 8.

\section{Antioxidant activity of isolated compound}

Antioxidant activity test was done by DPPH method with concentration variation 100, 50, 25, 12.5 and $6.75 \mathrm{ppm}$. Antioxidant activity is determined based on the value of $\%$ inhibition (Table 3). The higher the\% inhibition, the stronger the antioxidant activity
Table 3 showed the higher the concentration of the test the smaller the absorbance and the percent inhibition value will also be higher. Based on the percentage of inhibition seen at a concentration of $6.25 \mu \mathrm{g} / \mathrm{mL}$, the isolation compound results showed higher activity than the standard ascorbic acid. To determine the value of $\mathrm{IC}_{50}$, the plot curve between concentration and the value of $\%$ inhibition based on the linear regression. Base on regression linear obtained equation shows that $\mathrm{IC}_{50}$ value of the isolated compound is $8.25 \mu \mathrm{g}$ $/ \mathrm{mL}$, while the ascorbit acid gives $\mathrm{IC}_{50}$ value of $11.3 \mu \mathrm{g} / \mathrm{mL}$. Based on this data concluded the efficacy of supit plants (Tetracera indica) for the treatment related to antioxidant activity (uric acid) is proven by the identification of one antioxidant compound of this plant. Isolatet compound is flavonoid group.

Table 2. Chemical shift data of proton and carbon of the $1 \mathrm{H}$ and 13CNMR spectra of isolation compound at $500 \mathrm{MHz}$ for ${ }^{1} \mathrm{H}$ and $125 \mathrm{MHz}$ for ${ }^{13} \mathrm{C}$ in $\mathrm{CDCl}_{3}$.

\begin{tabular}{|c|c|c|c|}
\hline No $\mathrm{C}$ & $\delta_{\mathrm{C}}(\mathrm{ppm})$ & $\begin{array}{c}\delta_{\mathrm{H}}(\mathrm{ppm}), \text { integration, } \\
\text { multiplicity, } J(\mathrm{~Hz})\end{array}$ & HMBC \\
\hline 2 & 163.7 & & \\
\hline 3 & 105.4 & $6.69(1 \mathrm{H}, s)$ & $\begin{array}{c}106.1(\mathrm{C} 10), 131.4\left(1{ }^{\prime}\right) \\
182.4(\mathrm{C} 4)\end{array}$ \\
\hline 4 & 182.4 & & \\
\hline 5 & 149.0 & $12.49(1 \mathrm{H}, s)$ & \\
\hline $5-\mathrm{OH}$ & 12.69 & & $99.0(6), 106.1(10)$ \\
\hline 6 & 99.0 & $6.45(1 \mathrm{H}, s)$ & $\begin{array}{c}\text { 106.1(C10), } 127.0(\mathrm{H} 8), 155.4(\mathrm{C} 7), \\
157.9(\mathrm{C} 9)\end{array}$ \\
\hline 7 & 155.4 & & \\
\hline 7-OMe & & $4.24(3 \mathrm{H}, s)$ & $127.0(\mathrm{C} 8)$ \\
\hline 8 & 127.0 & & \\
\hline $8-\mathrm{OH}$ & & $6.43(1 \mathrm{H}, b r s)$ & 99.0(C6), 127.0(C8) \\
\hline 9 & 157.9 & & \\
\hline 10 & 106.1 & & \\
\hline 1 & 131.4 & & \\
\hline $2^{\prime}, 6{ }^{\prime}$ & 126.4 & $7.56(2 \mathrm{H}, m)$ & 131.4(1'), 129.4(C3',5') \\
\hline $3^{\prime}, 5$, & 129.4 & $7.91(2 \mathrm{H}, m)$ & 126.4( (2', 6’), 132.1 (C4') \\
\hline 4' & 132.1 & $7.57(1 \mathrm{H}, m)$ & $126.4\left(\mathrm{C} 2{ }^{\prime}\right)$ \\
\hline
\end{tabular}<smiles>COc1cc(O)c2c(=O)cc(-c3ccccc3)oc2c1O</smiles>

A

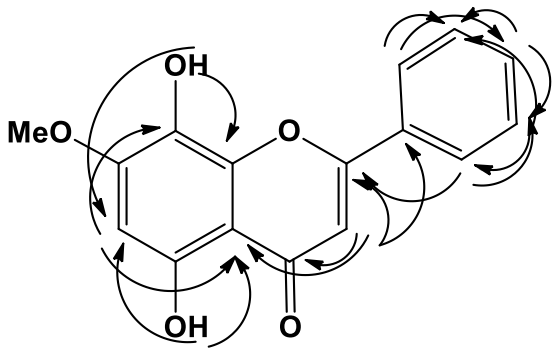

B

Figure 8. HMBC correlation (A) and structure isolation compound (B) 
Table 3. Antioxidant activity of isolated compound

\begin{tabular}{cccccc}
\hline \multirow{2}{*}{ No } & \multirow{2}{*}{ Concentration } & \multicolumn{2}{c}{ Isolated compound } & \multicolumn{2}{c}{ Ascorbic acid } \\
\cline { 3 - 6 } & & Absorbance & \% inhibition & Absorbance & \% inhibition \\
\hline 1 & 100 & 0.017 & 94.74 & 0.032 & 94.2 \\
2 & 50 & 0.019 & 94.12 & 0.082 & 85.0 \\
3 & 25 & 0.084 & 73.99 & 0.169 & 69.2 \\
4 & 12.5 & 0.091 & 71.83 & 0.275 & 49.8 \\
5 & 6.25 & 0.218 & 32.5 & 0.375 & 31.57 \\
\hline
\end{tabular}

Many flavonoids are shown to have antioxidant activity, such as for the prevention of coronary heart disease, hepatoprotective activity, anti-inflammatory, and anticancer (Kumar and Pandey, 2013).

The isolated compound 5,8-dihydroxy7-methoxyplavone was known by another name wogonin and has been previously found on the leaf extract (Dogarai et al., 2011) and stem extract of Ttetracera indica (Abdullah et al., 2013), but is first reported as active antioxidant against DPPH radicals.

\section{CONCLUSIONS}

A flavon compound has been isolated from ethyl acetate extract of the stem of supit (Tetracera indica) and identified as 5,8dihydroxy-7-methoxyplavone. This compound showed strong antioxidant activity by DPPH method with $\mathrm{IC}_{50}$ value $8.25 \mu \mathrm{g} / \mathrm{mL}$.

\section{ACKNOWLEDGEMENTS}

The authors are statement grateful to Sriwijaya University which research grant competitive 2017 supported this research.

\section{REFFERENCES}

Abdullah, F., Ismail, N.H., Jamaludin, F., \& Mashim, S.N.A.M. (2013). Xanthine Oxidase Inhibitory Activity of Tetracera Indica. Open Conference Proceedings Journal, 4, 93-94.

Ahmed, Q.U., Dogarai, B.B.S., Amiroudine, M.Z. Taher, M., Latip, J., Umar, A., \& Muhammad, B.Y. (2012). Antidiabetic activity of the leaves of Tetracera indica Merr. (Dilleniaceae) in vivo and in vitro. Journal of Medicinal Plants Research 6:5912-5922.

Brewer, M.S. (2011). Natural Antioxidants: Sources, Compounds, Mechanisms of Action, and Potential Applications. Comprehensive Reviews in Food Science and Food Safety, 10(4), 221-247

Chaudhary, A., Bhandari, A., \& Pandurangan, A.(2012). Antioxidant potential and total phenolic content of methanolic bark extract of Madhuca indica (koenig) Gmelin. Ancient Science of Life, 31(3),132-136.

Delowar, H., Shahid, S., Masudur, R. D., Shohel, H., Shahid, U..D, \& Mohammad, S.I.( 2014). Investigation of total phenolic content and antioxidant activities of Azadirachta indica roots, Avicenna Journal of Phytomedicine. 4(2), 97-102.

Dogarai, B.B.S. (2011). Phytochemical and antidiabetic activity investigations of Tetracera, Malaysia, International Islamic University,

Elfahmi, Herman, J., Woerdenbag, \& Oliver K. (2014). Јати: Indonesian traditional herbal medicine towards rational phytopharmacological use. Journal of Herbal Medicine, 4(2), 51-73

Ernie, H. P. (2013). Jamu, Obat Tradisional Asli Indonesia Pasang Surut Pemanfaatannya di Indonesia. Jamu, Obat Tradisional, 1 (2), 85-89.

Fitrya, Muharni, \& Maretha, K. (2012). Senyawa Fenolat dari Fraksi Etil Asetat Buah Tumbuhan Mempelas (Tetracera indica Merr.). Jurnal Penelitian Sains, 15(3), 107-110

Hanafi,M., Nina A, Zorni, F. \& Nurbaiti. (2005). Indonesian Country Report on Traditional medicine, BPPT, Indonesia

Kumar, S., Mishra, A, \& Pandey, A. K. (2013). Antioxidant mediated protective effect of Parthenium hysterophorus against oxidative damage using in vitro models. BMC Complementary and Alternative Medicine, 13, article 120.

Kumar, S \& Pandey, A. K. ( 2013). Chemistry and Biological Activities of Flavonoids: An Overview. The Scientific World Journal. 2013:1-16.

Lima, C.C., Lemos, R.P.L., \& Conserva, L.M. (2014). Dilleniaceae family: an overview of its ethnomedicinal uses, 
biological and phytochemical profile. Journal of . Pharmacognosy and.Phytochemistry, 3,181-204.

Kenari, R.E., Mohsenzades, F., \& Amiri, Z. R. (2014). Antioxidant activity and total phenolic compounds of Dezful sesame cake extracts obtained by classical and ultrasound-assisted extraction methods. Food Science and Nutrition. 2(4), 426435.

Mariod, A.A., Matthaus B., \& Hussein I.H. (2008). Antioxidant properties of methanolic extracts from different parts of Sclerocarya birrea. International Journal of Food Science \&Technology, 43, 921-926.

Michael, W. (2015). Modes of Action of Herbal Medicines and Plant Secondary Metabolites. Medicines , 2(3), 251-286.

Muharni, Fitrya, \& Nurmaliana, R. (2016). Skrining fitokimia aktifitas antioksidan dan antibakteri dari tumbuhan obat tradisional etnis Musi. Palembang.. Laporan Penelitian Ristoja Lanjutan, Depkes, Indonesia

Muharni, Elfita, \& Amanda, 2011, Biflavonoid from the stem bark of Gamboge (Garcinia xanthochymus). Indonesian Journal of Chemistry, 11(2), 169-173.

Paravicini, T.M. \& Touyz, R.M. (2008). NADPH Oxidases, Reactive Oxygen
Species, and Hypertension Clinical Implications and Therapeutic Possibilities. Diabetes Care, Clinical Implications and Therapeutic Possibilities. Diabetes Care, 31, S 170S180.

Rogerio, A.P, Sá-Nunes, A., \& Faccioli, L.H. (2010), The activity of medicinal plants and secondary metabolites on eosinophilic inflammation. Pharmacological Research. 62(4), 298307.

Selvi, A.T., G. (2003). Inhibition of growth and aflatoxin production in Aspergillus flavus by Garcinia indica extract and its antioxidant activity. Food Microbiologyl. 20, 455-460.

Tuanjai, N., Supalax, S., Thawatchai, Y., \& Wittaya, N., 2011. New approach for evaluation of the antioxidant capacity based on scavenging DPPH free radical in micelle systems. Food Research International, 44(3), 798-806.

Yustian, I., Muharni, Sukarmi, S., Zulaicha, \& Arbi, M., 2012. Riset khusus eksplorasi pengetahuan lokal etnomedisin dan tumbuhan obat di Indonesia berbasis komunitas (Wilayah Musi II). Palembang. Laporan Penelitian Ristoja, Departemen Kesehatan., Indonesia. 